ISSN 2073-445X

www.mdpi.com/journal/land/

Article

\title{
Regional Deforestation Trends within Local Realities: Land-Cover Change in Southeastern Peru 1996-2011
}

\section{Andrea Chávez Michaelsen ${ }^{1, *}$, Leticia Huamani Briceño ${ }^{1}$, Ronny Fernandez Menis ${ }^{1}$, Nemin Bejar Chura ${ }^{1}$, Frank Valera Tito ${ }^{1}$, Stephen Perz ${ }^{2}$, I. Foster Brown ${ }^{3}$, Sandro Domínguez Del Aguila ${ }^{4}$, Raúl Pinedo Mora ${ }^{5}$ and Gabriel Alarcón Aguirre ${ }^{1}$}

1 Geospatial Center for Natural Resource Management Research, Universidad Nacional Amazónica de Madre de Dios, Av. Jorge Chávez s/n, Puerto Maldonado, Peru;

E-Mails: letyhb15@hotmail.com (L.H.B.); rofe163@hotmail.com (R.F.M.); nylat_5@hotmail.com (N.B.C.); frank1748@hotmail.com (F.V.T.); galarcona@hotmail.com (G.A.A.)

2 Department of Sociology, Criminology \& Law, University of Florida, Gainesville, FL 32611, USA; E-Mail: sperz@ufl.edu

3 Zoobotanical Park and Setor of Land Use and Global Change Studies, Federal University of Acre and Woods Hole Research Center, Rio Branco, Acre, Brazil; E-Mail: fbrown@uol.com.br

4 Autoridad Nacional del Agua, Lima 27, Peru; E-Mail: sandro.dda@gmail.com

5 Proyecto Especial Madre de Dios, Gobierno Regional Madre de Dios, Iberia, Peru; E-Mail: raulpm7@hotmail.com

* Author to whom correspondence should be addressed; E-Mail: andreabirgitchavez@ gmail.com; Tel.: +51-989-655-036.

Received: 29 January 2013; in revised form: 8 March 2013 / Accepted: 19 March 2013 / Published: 10 April 2013

\footnotetext{
Abstract: Estimating deforested areas and deforestation rates have become key steps for quantifying environmental services of tropical rain forests, particularly as linked to programs such as Reduced Emissions from Deforestation and Forest Degradation (REDD). In Southeastern Peru, reliable estimates of land-cover change (LCC) are important for monitoring changes in the landscape due to agricultural expansion, pasture creation and other socio-economic influences triggered by the Inter-Oceanic Highway (IOH). Our study reports a land-use/land-cover change (LULCC) analysis during a 15-year period from 1996 to 2011 in the Province of Tahuamanu, Madre de Dios. We draw on multiple years of observations of LULCC to relate changes in land cover to the use of natural resources (pasture, timber, crops and forest products) and tenure types based on their distances from
} 
the highway and the Tahuamanu River. We are able to distinguish titled areas for agriculture close to the $\mathrm{IOH}$ from other land tenure types such as timber concessions. The findings show that LULCC varies among different types of land tenure and by distance from the highway. Agricultural areas close to transportation infrastructure within $1 \mathrm{~km}$ to $5 \mathrm{~km}$ buffers have gradually increased in non-forest areas, whereas timber concession areas away from $1 \mathrm{~km}$ buffer of secondary roads have maintained forest cover. Riverine settlements show a similar distance effect in forest clearance along rivers as along roads.

Keywords: land use; land cover change; change detection; Madre de Dios; Amazon; Peru

\section{Introduction}

The global community is increasingly facing a new level of global climatic threats that is affecting landscapes at unprecedented rates. Better monitoring of deforestation and improved collaborative research efforts to understand the causes of changes in the landscape are critical. The land-change science and global change research communities have made clear that a continued assessment of the dynamic nature of current changes is indispensable [1-6]. Estimating deforested areas and deforestation rates are key steps for quantifying the value of environmental services of tropical rain forests. In particular, understanding biomass carbon stocks and fluxes is key to creating incentives for programs such as Reduced Emissions from Deforestation and Forest Degradation (REDD).

In tropical Latin America, LULCC has been related to policies that prompted the development of the agricultural frontier [7-11]. Related to policies for expansion of agricultural frontiers in tropical forest areas are projects to build or pave roads [12,13]. In the Brazilian Amazon, major transportation infrastructure projects have been implemented to incorporate the region with the national economy and to open the Amazon frontier [10,14]. Road paving has encouraged regional growth and economic development by reducing transport costs, potentially making local economic activities viable for competition in markets, and increasing forest clearing beyond that needed for subsistence production [15]. However, infrastructure projects have also led to massive deforestation and increased carbon emissions that have contributed to global climate change [16-18]. Consequently, more than 60 percent of deforestation in the Brazilian Amazon has occurred within $50 \mathrm{~km}$ of major paved highways [19].

Conversely, in many areas of the Peruvian Amazon, the absence of infrastructure projects has hampered economic development [20,21], keeping deforestation rates relatively low, compared to those in neighboring countries [22]. Hence, in the case of Peru, the paucity of roads has preserved the world's eighth largest tropical forest area by country globally, with nearly 70 million hectares of natural forests or approximately $55 \%$ of the total national territory [23,24]. Nonetheless, the deforestation that has taken place in the Peruvian Amazon has occurred in close proximity to roads $[22,25,26]$.

The recent rise in deforestation in the Peruvian lowlands may be explained by new road infrastructure such as the paving of the Inter-Oceanic Highway (IOH) [27,28]. The IOH passes through

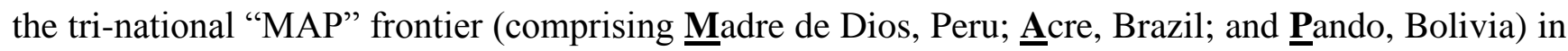
southwestern Amazonia and includes a 400-km section in the Peruvian lowland region of Madre de 
Dios. Paving of the IOH has stimulated debate as to its likely impacts, both on the regional economy and on LULCC [29,30].

In addition to expansion of transportation infrastructure, land tenure has played a key role in the way LULCC has evolved across space and over time [15,31,32]. Studies have shown how land tenure security has been associated with forest conservation and non-participation in timber extraction, while enforcement of protected areas has been used as a proxy for conservation success and avoided deforestation [33,34]. However, a defined land tenure system does not guarantee successful conservation of forests, and more empirical work on the impacts of land use, land cover, and resource tenure on LULCC is required [29,33].

These observations raise questions as to how land tenure institutions condition land use dynamics. For example, different resources within a given area may be held under different property rights regimes, leading to confusion and/or a lack of control over resource use. Rapidly changing conditions, such as the paving of the $\mathrm{IOH}$, may lead to increased migration, which fosters land tenure overlap and conflict. In some parts of the Peruvian Amazon such as Madre de Dios Region, land tenure and resource boundaries of agricultural and mining areas, protected areas, timber and Brazil nut concessions have for long co-existed without proper enforcement of their legal boundaries, which has led to land invasions and unsustainable resource extraction [34].

There remains a scarcity of information about deforestation trends in the Peruvian lowlands [35]. Official data on forest cover for the Peruvian Amazon imply that forest cover had hardly changed through the 1980s; nonetheless, deforestation has increased significantly since the early 1990s [36]. On the other hand, deforestation data for Peruvian forests have been inconsistent $[37,38]$. The accuracy of deforestation estimates has been controversial and questions endure due to the lack of an adequate monitoring system. While national and international measurements of deforestation are essential for credibility and quality assurance, local and regional deforestation estimates are critical because they guide the local actions on which future payments for environmental service (PES) programs such as REDD efforts will succeed. Efforts toward data standardization should allow for improved monitoring of spatial variation and temporal dynamics of deforestation.

This paper has three objectives. First, it shows how infrastructure and tenure serve as key examples of the effects of public policies on LULCC. Second, it presents a spatial analysis of LULCC by examining the effects of distance from the $\mathrm{IOH}$, as well as logging roads and rivers, to evaluate the importance of accessibility on LULCC. And third, the paper provides a temporal analysis that compares LULCC before, during and after paving of the IOH on lands with distinct tenure types, particularly agricultural lands and forest concessions.

\section{Study Region}

The study area is located in the province of Tahuamanu within the Peruvian Region of Madre de Dios (Figure 1). Tahuamanu Province had an estimated human population of 10,742 in 2007 (Source: National Institute of Statistics and Informatics [39]) and encompasses the Districts of Iñapari (1,485,300 ha), Iberia (254,900 ha) and Tahuamanu (379,300 ha). The region's vegetation consists largely of alluvial and terra firme forests with low hillside bamboo forest (Guadua sp.) [20,40]. Alluvial forests cover low terraces located alongside the borders of the major rivers and their areas 
change due to river migration. Terra firme forest is found above the alluvial terrain away from river courses and lakes and is typified by a diversity of forest types of relatively flat topography.

Our research design is based on the analysis of how policies for infrastructure (road paving) and land tenure categories in Tahuamanu likely affect LULCC. We will employ a spatio-temporal analysis of LULCC from 1996 to 2011 in three specific target areas (Figure 1, see I to III) in order to evaluate nonlinearities in LCC over time (due to road paving) as well as spatial differences (due to $1 \mathrm{~km}, 2 \mathrm{~km}$, and $5 \mathrm{~km}$ distances from the highway, secondary roads, and rivers, and among different types of land categories). Our three target areas and spatio-temporal LULCC analysis and LULCC expectations are:

- Target Area I. Agricultural lands along the IOH and its secondary roads

LULCC Expectations: We expect an increase in non-forest areas in private titled properties for agricultural use close to the paved $\mathrm{IOH}$, as well as in agricultural properties located adjacent to secondary roads after the paving of the $\mathrm{IOH}$.

- Target Area II. Timber Concession areas and Protected Areas

LULCC Expectations: We expect that timber concessions, protected areas, and indigenous communities near the IOH will maintain their forested areas. Despite their accessibility from the highway and secondary roads, we anticipate that users of these areas will follow tenure rules and conserve forest cover.

- Target Area III. Tahuamanu River Watershed Area

LULCC Expectations: Farther away from the $\mathrm{IOH}$, along the Tahuamanu River, we expect that timber concessions, protected areas, and indigenous communities will also maintain their forest areas compared to agricultural areas.

\subsection{Policy Shifts and LULCC}

Policy shifts and a series of economic boom-bust cycles have influenced LULCC in the region of Madre de Dios [41]. Rubber was important between the early 1900s and 1950s in the District of Iberia, attracting the first wave of migrants to the area [42]. Since the 1980s, the Province has been a key area for logging concessions, and a timber boom began in the late 1990s [43]. Furthermore, between 1985 and 1990 the Garcia regime launched policy incentives for cattle and pasture expansion [41]. Increased access to agricultural credit and support for cattle acquisition facilitated forest clearing, especially for cattle pasture during this time period [25,35]. In addition, in 1986, colonization policy efforts organized by Special Project of Madre de Dios (PEMD) sent 120 families from Arequipa and Puno to be settled in the communities of Primavera and Chilina along the IOH in the districts of Iñapari and Iberia. Most migrants in the Province of Tahuamanu came from the Andean Regions of Cusco, Puno and Apurimac and even from neighboring Brazil [44]. These colonization projects never received the promised support from the government such as basic housing, education and medical facilities. Consequently, an estimated $70 \%$ of migrants arriving with these colonization programs relocated or returned to their regions of origin [21]. 
Figure 1. The Province of Tahuamanu (shaded yellow) in Madre de Dios Region showing the three areas where analysis was conducted (I-III).

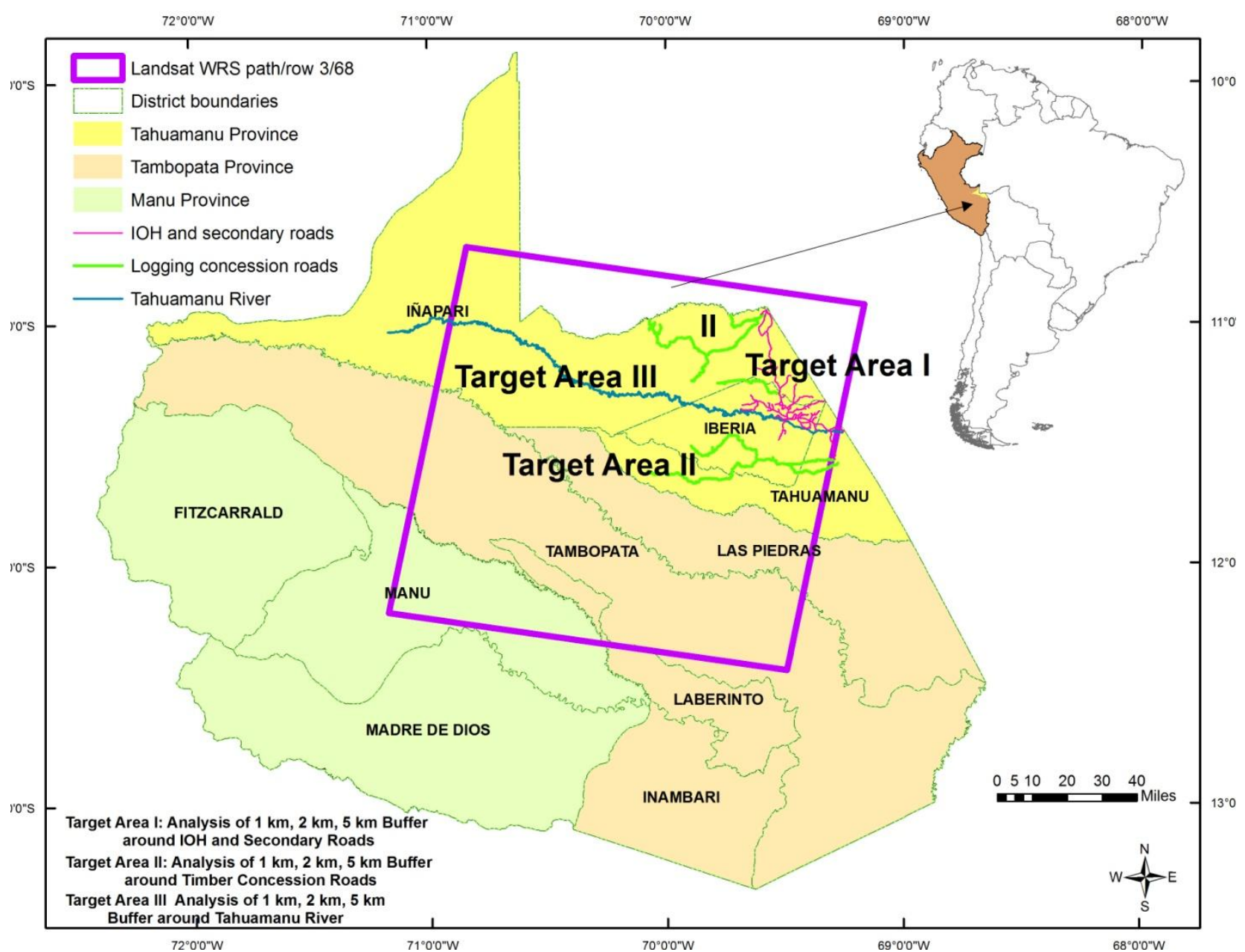

Furthermore, the agricultural credit programs that existed between 1985 and 1990 could not be sustained due to the worsening fiscal crisis in Peru. As a result, during the 1990s, pasture incentives and agricultural credit were withdrawn. Some areas deforested during 1985-1990 reverted back to forest in the 1990s, resulting in an increase in secondary forests [41,44]. During the early 2000s, government incentives were reintroduced, this time to help farmers expand production, improve product quality, and pursue processing and marketing of crops such as coffee, cacao, and peppers. At the same time, some policies included incentives for reforestation and seed improvement [45]. Currently, while no policies support commercial agriculture or ranching, farmers continue to open up land for pasture and agriculture. The District of Iberia has seen the establishment and expansion of the agrarian religious community Arca Pacahuara since 1995. These migrants from the Andean region have doubled in population from 2007 to 2010 close to the town of Iberia and are opening vast areas of land for agriculture [46]. At the present time, Arca Pacahuara reports 6,300 ha of titled land, which has been distributed in 30 ha plot for each household. The community holds land possession certificates for another 2,700 ha which are distributed the same way (Personal communication, resident from Arca Pacahuara). Some of Arca Pacahuara's land overlaps timber concessions and is currently in dispute. 


\subsection{Tenure Categories, Land Uses and Their LCC Impacts}

The Province of Tahuamanu presents five clearly differentiated land tenure categories: (1) private landholdings for agriculture; (2) timber concessions; (3) castaña ("Brazil nuts," Bertholletia excelsa) concessions; (4) Indigenous Communities; and (5) natural protected areas (Alto Purus National Park and Purus Communal Reserve) and the Territorial Reserve for Indigenous People in Voluntary Isolation (Territorial Reserve of Madre de Dios) [47] (Figure 2). These tenure categories are related to the economic base of the population in the Province of Tahuamanu which is centered on six main activities: subsistence farming, cattle, fish farming, timber extraction, castaña extraction, and tertiary services [48]. For the purpose of our analysis, we focus on the following land uses: subsistence farming, fish farming, cattle, timber extraction, and castaña extraction. In this section, we will describe these land uses and explain problems of overlap among tenure types and their implications for LULCC analysis.

Figure 2. Land Tenure Distribution in the Provinces of Tahuamanu and adjacent areas in Madre de Dios (Source: Instituto Nacional de Recursos Forestales (INRENA) and Proyecto Especial de Titulación de Tierras (PETT)).

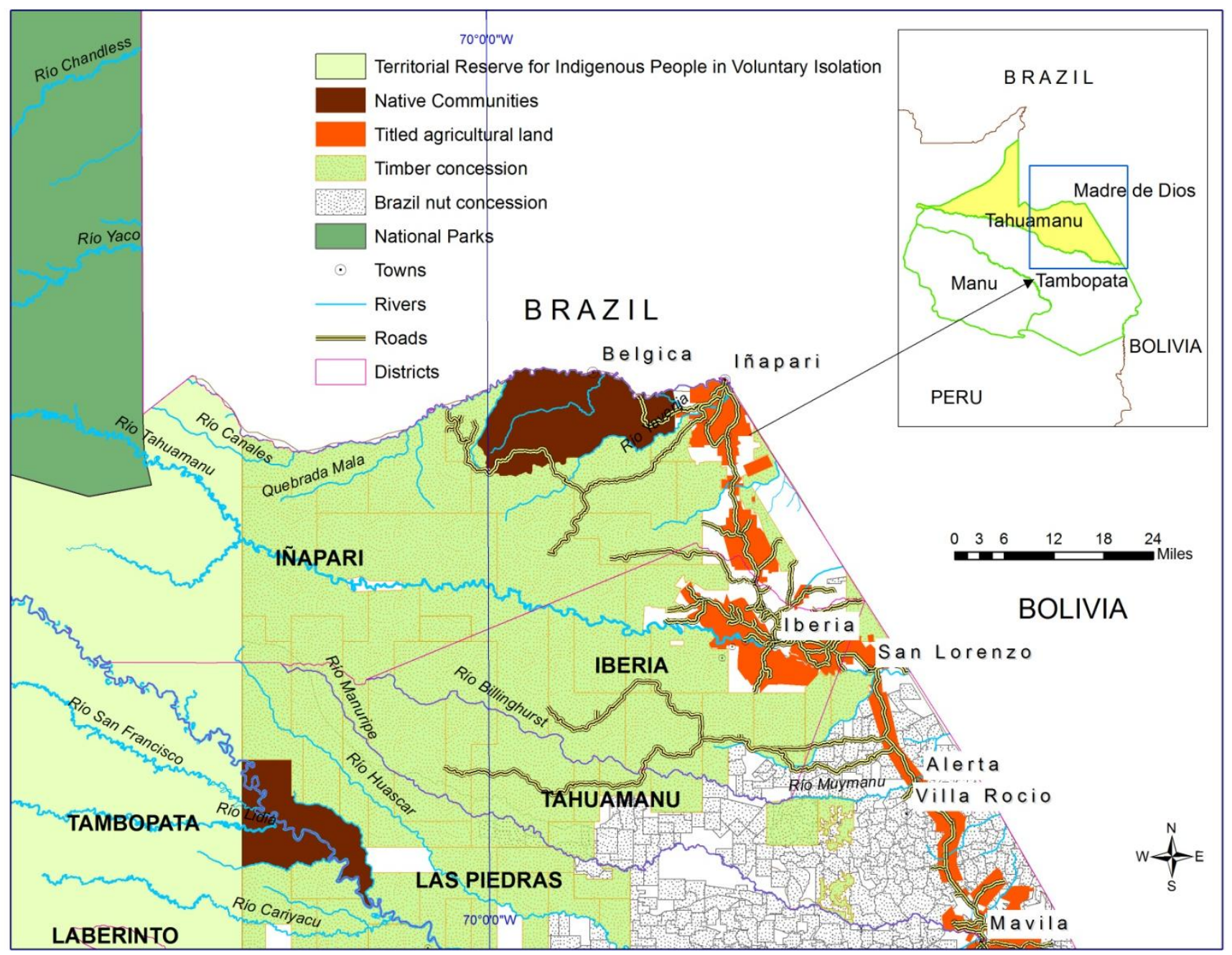




\subsubsection{Agricultural Properties}

Lands designated for agriculture exhibit very different LULCC than the other tenure categories in Tahuamanu. There is considerable potential for agricultural expansion to greatly impact LULCC in Madre de Dios. However, commercial agriculture has not historically played a major role in the region's economy [21]. The most important annual and perennial crops include: rice, maize, plantain, manioc, beans, citrus, and coffee. Table 1 shows that the most important crops by area in 2009 in Tahuamanu were maize and rice, with $22 \%$ and $14 \%$ respectively. However, most agricultural land (53\%) was devoted to pasture. While livestock in the Province of Tahuamanu represents approximately $21 \%$ of the overall regional production, the District of Iñapari has seen the largest increase in cattle [49]. For example, cattle statistics reported in 2009 for the Province of Tahuamanu are 12,231 heads in comparison to the latest statistics on human population in 2007 of 10,742 (Source: National Institute of Statistics and Informatics [39,40]).

Table 1. Agricultural Crop Production with Pasture for Livestock Forage in 2009 for the Province of Tahuamanu, Madre de Dios, Peru (Source: Adapted from [50]).

\begin{tabular}{ccc}
\hline Agricultural Land Use & Area in ha & Percentage \\
\hline Brachiaria Grass & 3,453 & 53 \\
Maize & 1,451 & 22 \\
Rice & 902 & 14 \\
Plantain & 150 & 2 \\
Beans & 135 & 2 \\
Manioc & 130 & 2 \\
Yaragua Grass & 116 & 2 \\
Papaya & 35 & 0.5 \\
\hline
\end{tabular}

Fish farming is not listed as a major economic activity in the Province of Tahuamanu. Fish farming gradually started in the early and mid 2000 when PEMD granted machinery equipment and technical support to farmers. Fish farming has seen a steady increase along the IOH and less along the rivers, and is considered a growth activity in Tahuamanu, especially in the District of Iñapari [51,52]. While fish farming has benefited from highway paving, maintaining young fish is costly and demands substantial start-up capital [51]. Fish farming areas are expected to increase cleared areas along the $\mathrm{IOH}$ and to impact LULCC.

There is an increasing problem of overlap among tenure types and consequent conflicts among LULCC. In Peru, different institutions have been in charge of granting property rights. Rural land titling for agricultural purposes and for indigenous lands have been executed via the Ministry of Agriculture, via the Special Land Titling and Rural Cadastre Project (PETT) from 1992 to 2008. The major objectives of PETT were to encourage land titling, create a cadastre database, and formalize land ownership. Since 2008, the Commission for the Formalization of Informal Property (COFOPRI) has taken over management of titling procedures and began to transition responsibilities to regional governments. Nonetheless, titling procedures have been highly complex, inconclusive, and thus unclear in rural settings. In this context, increased land occupation has created conditions for overlaps among land claims with differing land uses. For example, the expansion of agricultural land into 
timber concessions or vice versa has opened forested lands and affected LULCC. On the other side, tenure conflict overlap has been reported between mining, and Brazil nut and timber concession areas. These conflict overlaps are less pronounced in our study area.

\subsubsection{Timber and Castaña Concessions and Protected Areas}

In contrast to agricultural properties, other tenure categories in Tahuamanu exhibit largely forest-based LULCC. One key example concerns timber concessions. Table 2 gives an overview of recent timber production in Madre de Dios. These overall numbers do not include timber extracted from agricultural lands, indigenous communities and reforestation concessions, which would add substantially more to the reported timber production [53]. In the case of Iberia District, timber extracted from titled agricultural lands is seven times the official amount reported from timber concessions [49].

More recently, Iñapari District has seen negotiations for sustainable forest management (SFM) through the production of certified wood for the sale of environmental services derived from avoided deforestation under REDD [54-56]. While certification for SFM is intended to encourage forest conservation and thus avoid deforestation, certification and actual practices may nonetheless diverge.

Table 2. Roundwood and Sawn Timber Production in cubic meters from 2000 to 2010 for the Region of Madre de Dios, Peru (Source: INEI Perú: Anuario de Estadísticas Ambientales 2011/MINAG-INRENA/MINAG-DGFFS: Perú Forestal en Números 2000-2010).

\begin{tabular}{ccc}
\hline Year & Roundwood Production in $\mathbf{~ m}^{\mathbf{3}}$ & Sawn Timber Production in $\mathbf{~ m}^{\mathbf{3}}$ \\
\hline 2000 & 266,611 & 138,105 \\
2001 & 132,191 & 68,475 \\
2002 & 163,629 & 85,223 \\
2003 & 175,376 & 91,341 \\
2004 & 158,530 & 72,316 \\
2005 & 191,410 & 86,728 \\
2006 & 251,636 & 84,405 \\
2007 & 196,652 & 99,665 \\
2008 & 253,498 & 128,377 \\
2009 & 290,449 & 139,315 \\
2010 & 330,659 & 134,614 \\
\hline
\end{tabular}

The granting of concessions for timber and non-timber extraction was regulated by the National Institute of Natural Resources (INRENA) until 2010 when the regional governments began to take charge after a two-year transition period. Overall, the demarcation of specific land uses, such as timber and castaña concessions, private agricultural lands, as well as mining concessions all relevant to Madre de Dios are still under the jurisdiction of different agencies, pursuant to transfer of governmental functions from national agencies to regional government departments. This has led to a mixture of regional and governmental claims to jurisdiction and unclear control over resources. The result has been weak monitoring and sanctions systems that in turn foster negative ramifications for LULCC.

Protected areas are regulated by the Natural Protected Areas System (SINANPE), which was managed until 2008 by the Ministry of Agriculture, when its functions were reassigned to the National Service for Natural Protected Areas (SERNANP) under the newly created Ministry of Environment [57,58]. Resource 
use within protected areas and indigenous communities include subsistence agriculture, hunting, fishing, gathering, and to some extent timber and non-timber extraction [58]. However, natural protected areas have long been impacted by illegal logging and mining, and land use conversion for crops and pasture areas. The impact of illegal logging for LULCC is very difficult to assess.

\subsection{Transportation Routes and Their LULCC Impacts}

Aside from land tenure, new infrastructure is likely to affect LULCC in Tahuamanu. Tahuamanu has long benefitted from closer relationships with western Brazil than with government departments and agencies in Peru. Brazil has sought trade with Peru since the late eighteenth century, when river traders from Brazil exchanged crude manufactured goods such as steel and clothing for Peruvian salted fish, wood resins, balsams, and wax [59]. Transport infrastructure long consisted of dirt roads and mule trails, which were passable only during the dry season. The main alternative, rivers, also afforded transport, but that option was limited by non-navigable stretches $[21,45]$.

Beginning in the 1960s, Madre de Dios saw its first overland transportation route opened via the road from Puerto Maldonado, the capital of Madre de Dios, to the neighboring regional capital of Cusco. However, it was not until 1981, when the Madre de Dios Special Project (PEMD) was created, that the construction of a dirt road between Puerto Maldonado to Tahuamanu and the frontier town of Iñapari was initiated. PEMD is a governmental institution that was created in 1981 with the objective to foster development in the region between Puerto Maldonado and the border town of Iñapari. During the 1990s, segments of the prospective IOH were surveyed, leveled, and maintained. However, they allowed safe passage only during the dry season.

In the 2000s, the unpaved road from Puerto Maldonado to Iñapari was compacted, surfaced with gravel and prepared for paving, which began at the end of 2005 [60]. These investments occurred in the context of the Initiative for Integration of Regional Infrastructure in South America (IIRSA), led by Brazil [27,28]. The route through Tahuamanu became part of the Inter-Oceanic Highway, a premier project under the first phase of IIRSA [61].

Table 3. Selected demographic data for Madre de Dios Region and Tahuamanu Province (Source: Adapted from: [52]).

\begin{tabular}{cccccc}
\hline & $\begin{array}{c}\text { Iñari } \\
\text { District }\end{array}$ & $\begin{array}{c}\text { Iberia } \\
\text { District }\end{array}$ & $\begin{array}{c}\text { Tahuamanu } \\
\text { District }\end{array}$ & $\begin{array}{c}\text { Tahuamanu } \\
\text { Province }\end{array}$ & $\begin{array}{c}\text { Madre de } \\
\text { Dios Region }\end{array}$ \\
\hline Population 1972 & 504 & 4,015 & 817 & 5,336 & 25,174 \\
Population 1981 & 812 & 3,013 & 1,103 & 4,928 & 35,788 \\
Growth Rate 1972-1981 & 5.4 & -2.4 & 3.4 & -0.2 & 3.9 \\
Population 1993 & 870 & 3772 & 1,744 & 6,443 & 71,636 \\
Growth Rate 1981-1993 & 0.6 & 1.9 & 3.9 & 2.3 & 6.1 \\
Population 2007 & 1,288 & 6,715 & 2,739 & 10,742 & 109,600 \\
Growth Rate 1993-2007 & 2.8 & 4.2 & 3.3 & 3.7 & 3.1 \\
\hline
\end{tabular}

The $\mathrm{IOH}$ has however raised concerns about increased migration, new land settlement, social conflicts, and rapid LULCC [27,28]. The paving of the IOH has increased the network of secondary roads and has accelerated population growth in Tahuamanu Province. As Table 3 shows, population 
growth accelerated in Tahuamanu from the 1981-1993 period to the 1993-2007 period (Source: National Institute of Statistics and Informatics [21,39]). Indeed, whereas growth had been faster elsewhere in Madre de Dios during 1981-1993, during paving of the IOH, it became faster in Tahuamanu Province than elsewhere in Madre de Dios. This raises questions about recent LULCC accompanying this rise in population in the context of paving the $\mathrm{IOH}$.

\subsection{Remote Sensing and Survey Data}

To evaluate LULCC in Tahuamanu over time, we used Landsat TM 5 images for the years 1996, 2006, 2010, and 2011 and ETM+ for the year 2001 which fall within the Landsat World Reference System (WRS) Path 003 and Row 68. These satellite images were chosen based on cloud-free image availability during the dry season from June to September (Table 4).

Table 4. Landsat image acquisition information.

\begin{tabular}{cc}
\hline Sensor & Image Date \\
\hline Landsat 5 TM & 23 July 1996 \\
ETM+ Landsat 7 & 29 July 2001 \\
Landsat 5 TM & 16 May 2006 \\
Landsat 5 TM & 30 July 2010 \\
Landsat 5 TM & 3 September 2011 \\
\hline
\end{tabular}

All image preprocessing and analysis was conducted with ERDAS Imagine 9.2. Geometric rectification and registration were completed using the nearest-neighbor resampling technique with a Root Mean Square (RMS) error between 0.1 and 0.4 pixels for all images. The images were radiometrically calibrated following the CIPEC (Center for the Study of Institutions, Population, and Environmental Change) calibration method [62].

In this study, we employed tasseled cap indices in order to detect changes in LC categories across observation dates. Several change detection studies report landscape changes by employing Tasseled Cap (TC) transformed Landsat data [63-68]. Change detection using multi-date TC improves the recognition of spectral transformation change $[69,63]$ by linking data contained in discrete spectral bands with the physical attributes of landscape features. Brightness, wetness, and greenness (BWG) indices are sensitive to phenological changes and enhance vegetation classification [70,71]. Greenness distinguishes the near-infrared and visible bands, and determines the occurrence of green vegetation [72]. Wetness separates the infrared and near-infrared reflectance and is associated with soil moisture content and vegetation density, providing a more accurate demarcation between sites becoming greener and those that are senescing [71]. Further, the wetness band is linked to shadows and forest stand density and improves the identification of matured and well-established forest stands [73]. Notably, these correlations improve the distinctions between forest classes and within vegetation structure $[74,75]$.

According to [73], brightness and greenness indices decrease for mature or primary forest due to shadowing effects stemming from canopy height differences in the later stages of succession. Reports by [69] demonstrate high values of wetness for primary forest areas and stable regrowth sections. Regenerating forests show increased values of greenness, while brightness is dependent on soil color 
and moisture content, making seasonal variations a determinant factor. TC transformations have been successful in discriminating close to 95 percent of the total variability in the visible and near infrared spectrum, revealing variation in forest conditions [69], making it useful for the identification of forest classes even in tropical forests [71,76].

We therefore calculated tasseled-cap indices for the images for each date and used the results to detect changes in forest, non-forest, and water. We produced BWG indices for all Landsat images using Landsat 5 TM coefficients for 1996, 2006, 2010 and 2011. We also produced Landsat 7 coefficients for the 2001 image following [70,77,78]. TC classifications and distinctions within vegetation structures were based on studies by [75] and TC performance for the Amazon by [69].

Each Landsat image (visible and near-infrared bands) was stacked with its respective TC images to generate a nine-band composite [69]. We used a combination of unsupervised and supervised techniques through maximum likelihood classification and ground-data training signatures to assemble spectrally similar classes into a "forest," "non-forest," and "water" classification map for each year for which we have imagery. The finalized classes are defined as follows. "Forest" includes alluvial and terra firme forest, secondary forest, and low hillside bamboo forest (Guadua sp.). Our understanding of forest classes is based on [79] which defines a forest as having a canopy closure of more than 30\%, within an area of more than 0.5 ha and accounting for tree heights of more than $5 \mathrm{~m}$. "Non-forest" includes urban areas (towns), roads, crops and pasture. We count opening of logging roads, secondary roads, skid trails, and milling operations as non-forest in timber concessions. We also classify as non-forest those areas less than 10\% canopy closure [80]. Forest classes between 10\% and 30\% canopy closure range were assigned in our analysis to forest, since they represent in most cases different stages of secondary forest. Finally, "water" includes rivers, creeks and riverbanks.

To evaluate the classifications, we collected training sample for each land cover during field visits in 2003, 2004, 2005, 2008, 2010, and 2011. In total, we collected 788 training samples over the years that included information on the land cover class, canopy closure, and vegetation height. We further benefited from extensive field surveys of farmers and small-scale timber concession owners that reported on past LULCC dynamics [44]. We used training samples collected in 2003, 2005 and 2008 for creating initial land cover signatures of the 2001 and the 2006 classifications, and training samples collected in 2010 and 2011 for creating land cover signatures of the 2010 and 2011 classifications. The accuracy of the classified 2010 image was evaluated by choosing approximately 50 of the training samples for each forest, non-forest, and water class as determined by [81]. Training samples would always be excluded in the classifications). We followed a rigorous accuracy validation for the 2010 image since we were able to corroborate field data from the same year samples were taken with the corresponding 2010 classified image. The validation for the 2001, 2006, and 2011 classifications included a lower number of training samples collected in 2003, 2005, and 2011. Accuracies for the 2001 and 2006 classifications are $87 \%$ and $90 \%$, respectively [44], and $88 \%$ for the 2011 classification. The reported overall accuracy for the 2010 classification is $92 \%$ (Table 5).

We analyzed changes in forest, non-forest, and water in the three target areas noted above: (1) agricultural private lands along the Inter-Oceanic Highway and its secondary roads; (2) timber concession areas along timber concession roads; and (3) along the Tahuamanu River. We created $1 \mathrm{~km}$, $2 \mathrm{~km}$, and $5 \mathrm{~km}$-buffers around the IOH and Tahuamanu River and analyzed changes in forest/nonforested areas. 
Finally, after classifying the images, we performed simple change detection through pixel-based image differencing on the classified images 1996-2001, 2001-2006, and 2006-2011 to provide general information about changed areas [82].

Table 5. Error matrix for the 2010 classified forest/non-forest data accuracy assessment.

\begin{tabular}{|c|c|c|c|c|c|c|}
\hline \multicolumn{7}{|c|}{2010 Reference Data } \\
\hline \multirow{7}{*}{ 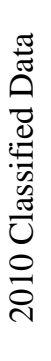 } & & FOREST & NON-FOREST & WATER & Classified Total & User's Accuracy \\
\hline & FOREST & 60 & 4 & 2 & 66 & 0.90 \\
\hline & NON-FOREST & 2 & 54 & 1 & 57 & 0.95 \\
\hline & WATER & 5 & 1 & 38 & 43 & 0.88 \\
\hline & Reference Total & 67 & 55 & 41 & 166 & \\
\hline & Producer's Accuracy & 0.89 & 0.98 & 0.93 & & \\
\hline & \multicolumn{6}{|c|}{ Overall Accuracy $=0.915$} \\
\hline
\end{tabular}

\section{Results and Discussion}

\subsection{Results on Temporal and Spatial Variation in LULCC Based on before, during, and after Paving}

In order to understand the changes in LULCC in the Province of Tahuamanu we provide a general overview of the temporal dynamic, followed by the spatial variation. We then break down the study area by distance from highway and land tenure type.

The results of the temporal dynamics at the provincial level are shown in Figure 3. Deforestation is not very advanced at the provincial level. There has been a very slight decline of approximately $2 \%$ in the forest area between 1996 and 2010. The results reveal that non-forest areas increase with the planning of the $\mathrm{IOH}$ in the early 2000, and progressively thereafter in the mid-2000 with the completion of the paving of the $\mathrm{IOH}$.

Figure 3. Forest, non-forest and water land-cover change temporal dynamic for 1996, 2001, 2006, 2011 for the Province of Tahuamanu.

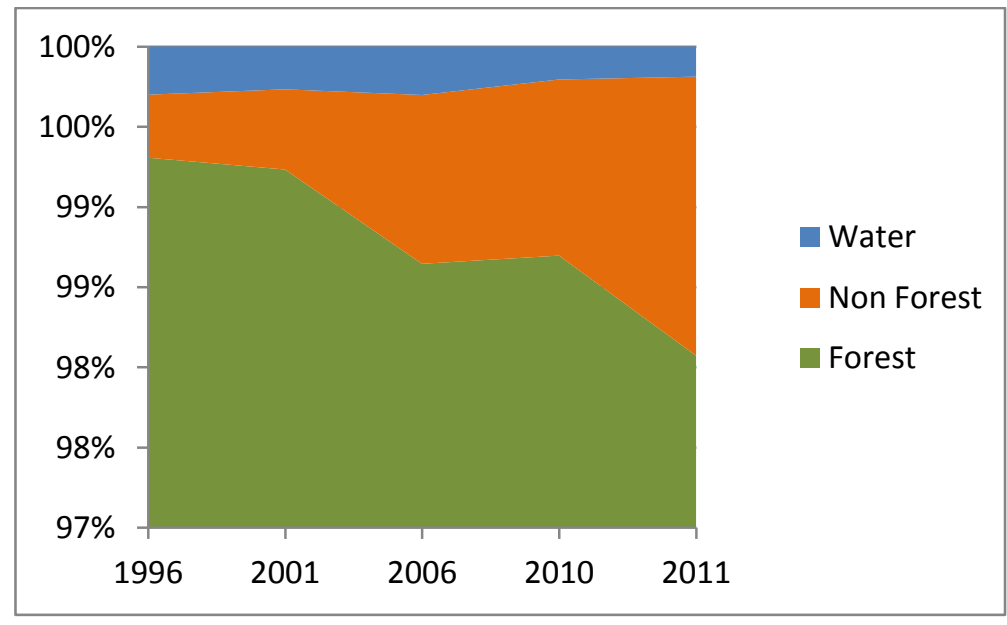

Detection of change areas through image differencing are shown in Figure 4 which highlight areas of pixelwise subtraction of the 1996-2001, 2001-2006, and 2006-2011 images. A gradual increased change from 7,770 ha in the 1996-2001 to 19,516 ha in the 2006-2011 change trajectory periods 
provide further evidence as to how road pre- and post-paving have influenced the temporal dynamics in LULCC.

Figure 4. 1996-2001, 2001-2006, and 2006-2011 image differencing change detection in the study area within the WRS Path/Row 368.
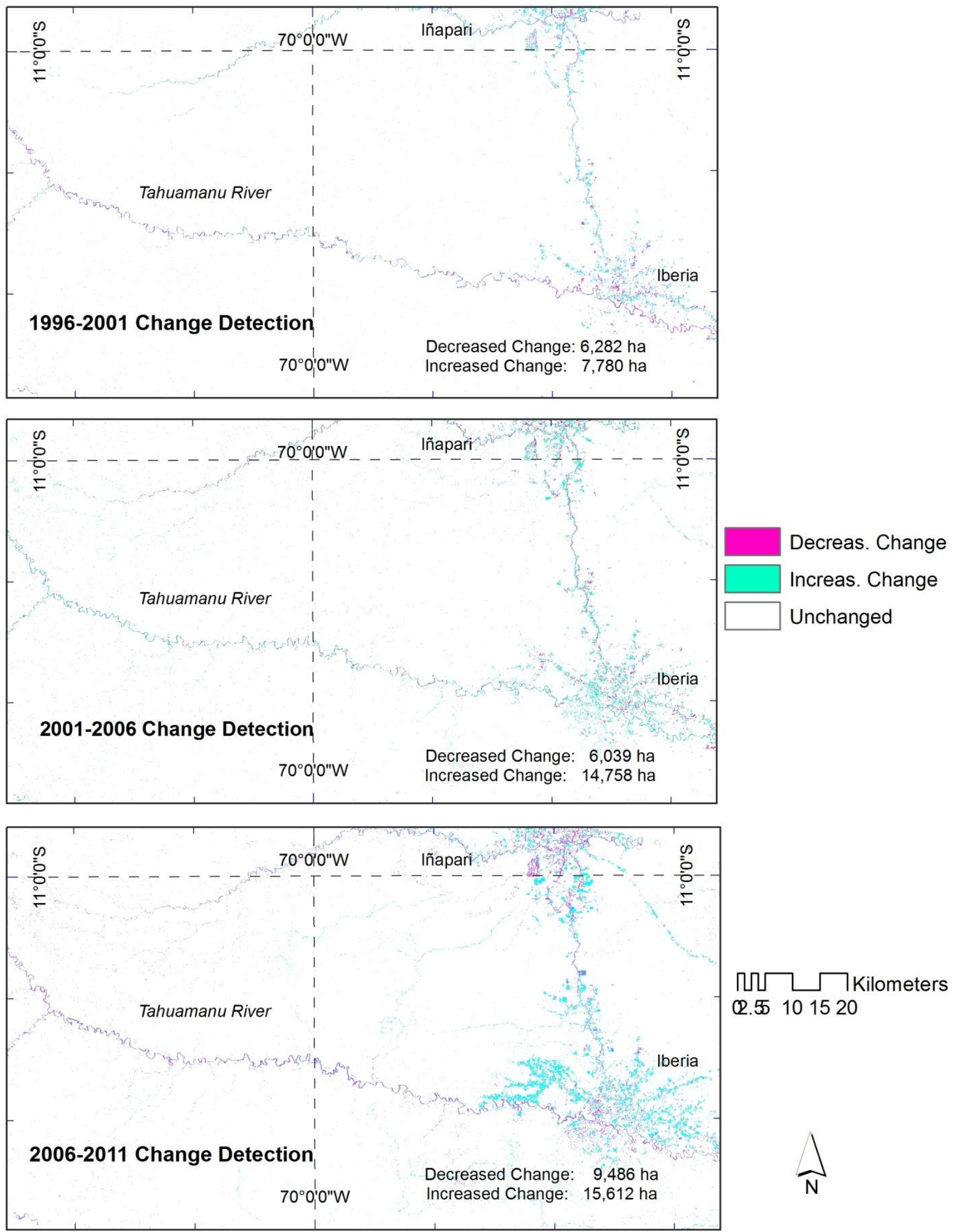
A sequence of forest, non-forest and water class maps produced for 1996, 2001, 2006, 2010, 2011 confirm that deforestation is not very extensive for the overall Province of Tahuamanu (Figure 5). That said, it is locally important along roads and rivers. It is here, where non-forest areas increased fourfold from 1996 to 2011. This finding corresponds to previous work on accessibility and LCC.

Figure 5. Forest, non-forest and water class maps for 1996, 2001, 2006 and 2011 for the Province of Tahuamanu. Areas of each class (in ha) are provided in the accompanying table.
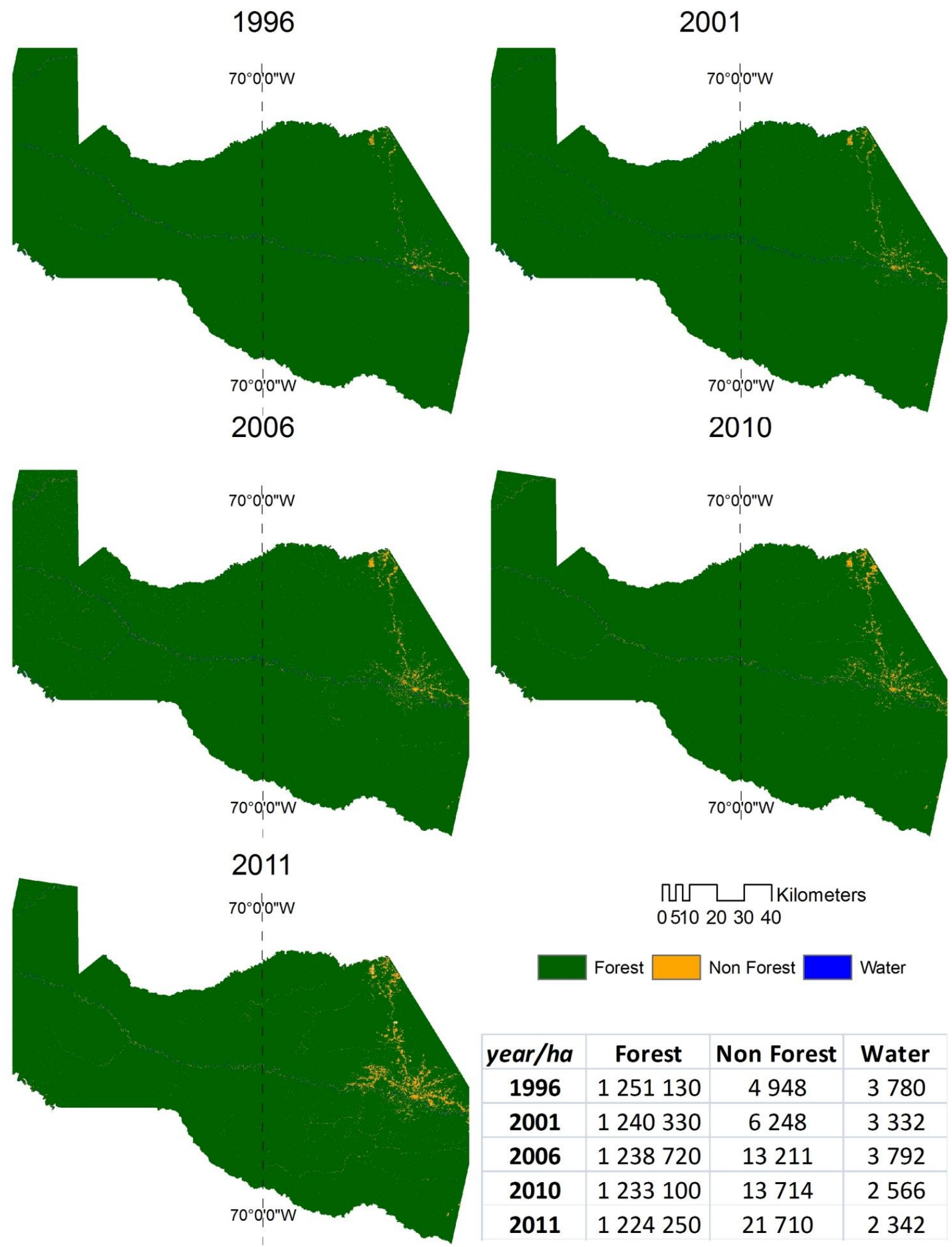
Spatial variation in forest loss, both by distance from the IOH and other roads as well as rivers, and by land tenure type provides greater detail in understanding how accessibility affects LULCC in Tahuamanu. Non-forest areas decline with distance from the IOH and other roads. Changes from 2010 to 2011 are much higher in comparison to more gradual changes of previous years. For example, non-forest areas almost doubled in size from 13,714 ha to 21,710 ha in 2011 (Figure 5). These trends reveal an increase in private titled agricultural lands along the $\mathrm{IOH}$.

\subsection{Results on Temporal Variation and Spatial Variation in LULCC Based on Distance from} Highway, Timber Concession Roads, and Tahuamanu River Watershed

Comparisons of LULCC among specified distance buffers from the IOH and secondary roads $(1 \mathrm{~km}, 2 \mathrm{~km}$, and $5 \mathrm{~km}$ ) show that there is more non-forest cover closer to infrastructure. Figure 6 confirms this relationship for agricultural properties while Figure 7 does so for timber concessions.

Figure 6. Forest, non-forest and water land-cover change dynamic of $1 \mathrm{~km}, 2 \mathrm{~km}$, and $5 \mathrm{~km}$ road buffer within agricultural titled land for 1996, 2001, 2006, 2011 for the Province of Tahuamanu.
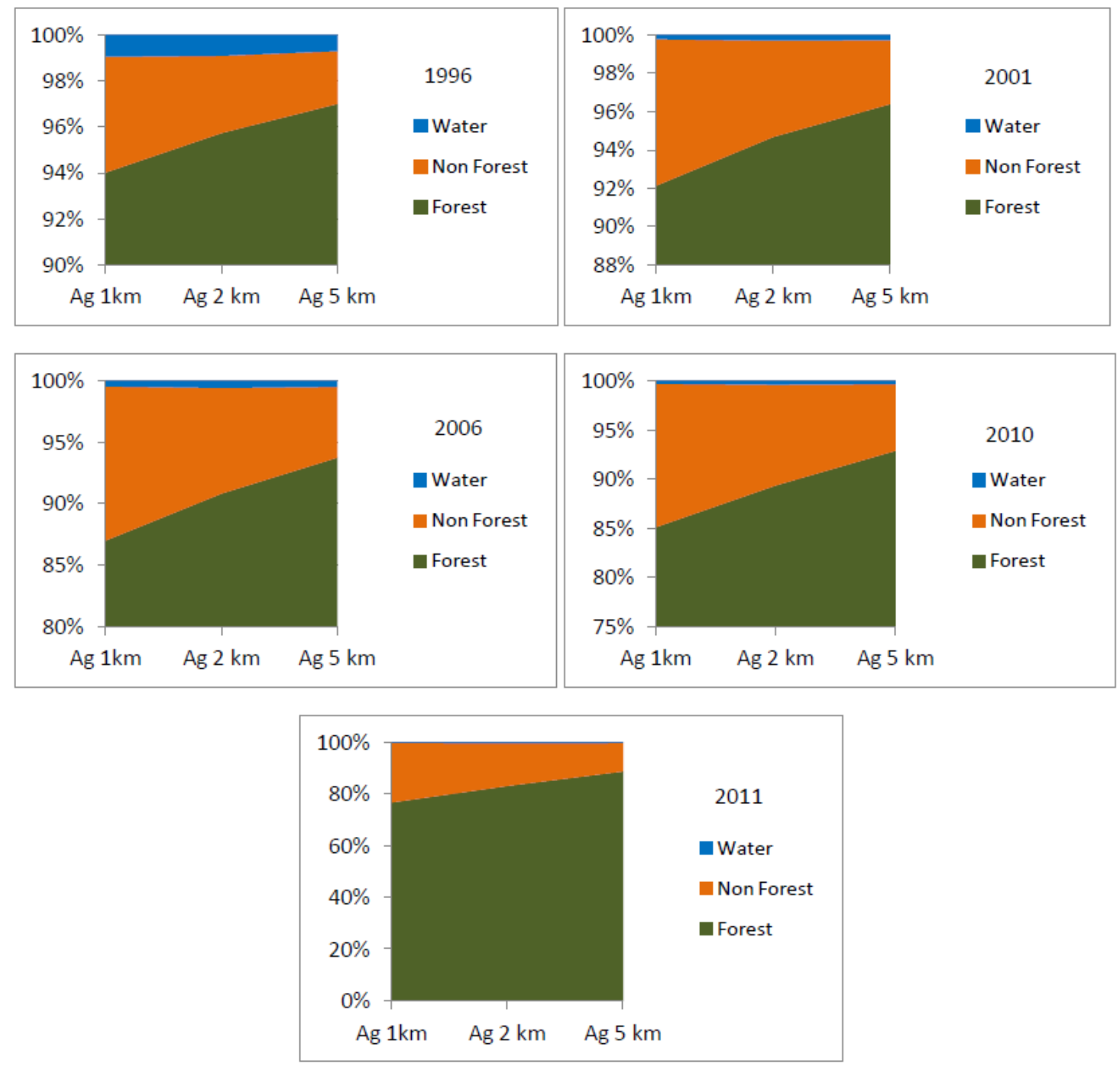
According to Figure 6, non-forest areas increased between 1996 and 2010 along the IOH and its secondary roads, from about 3\% (1996 approximately 5\% non-forest at $1 \mathrm{~km}$ and $2 \%$ at $5 \mathrm{~km}$ ) to about $12 \%$ in 2010 (approximately 75\% at $1 \mathrm{~km}$ and $87 \%$ at $5 \mathrm{~km}$ ). Further changes in 2011 show an increasing trend. The areas with the highest LULCC correspond to agricultural lands along the IOH with the highest population density. In particular, the areas within the town of Iberia and its increased secondary road networks have seen an increase in land conversion mainly for pasture and to a lesser extend for crops and fish farming. As expected, LULCC was much greater within the $1 \mathrm{~km}$ buffer zones within private titled agricultural lands.

Figure 7. Forest, non-forest and water land-cover change dynamic of $1 \mathrm{~km}, 2 \mathrm{~km}$, and $5 \mathrm{~km}$ road buffer within timber concession areas for 1996, 2001, 2006, 2011 for the Province of Tahuamanu.
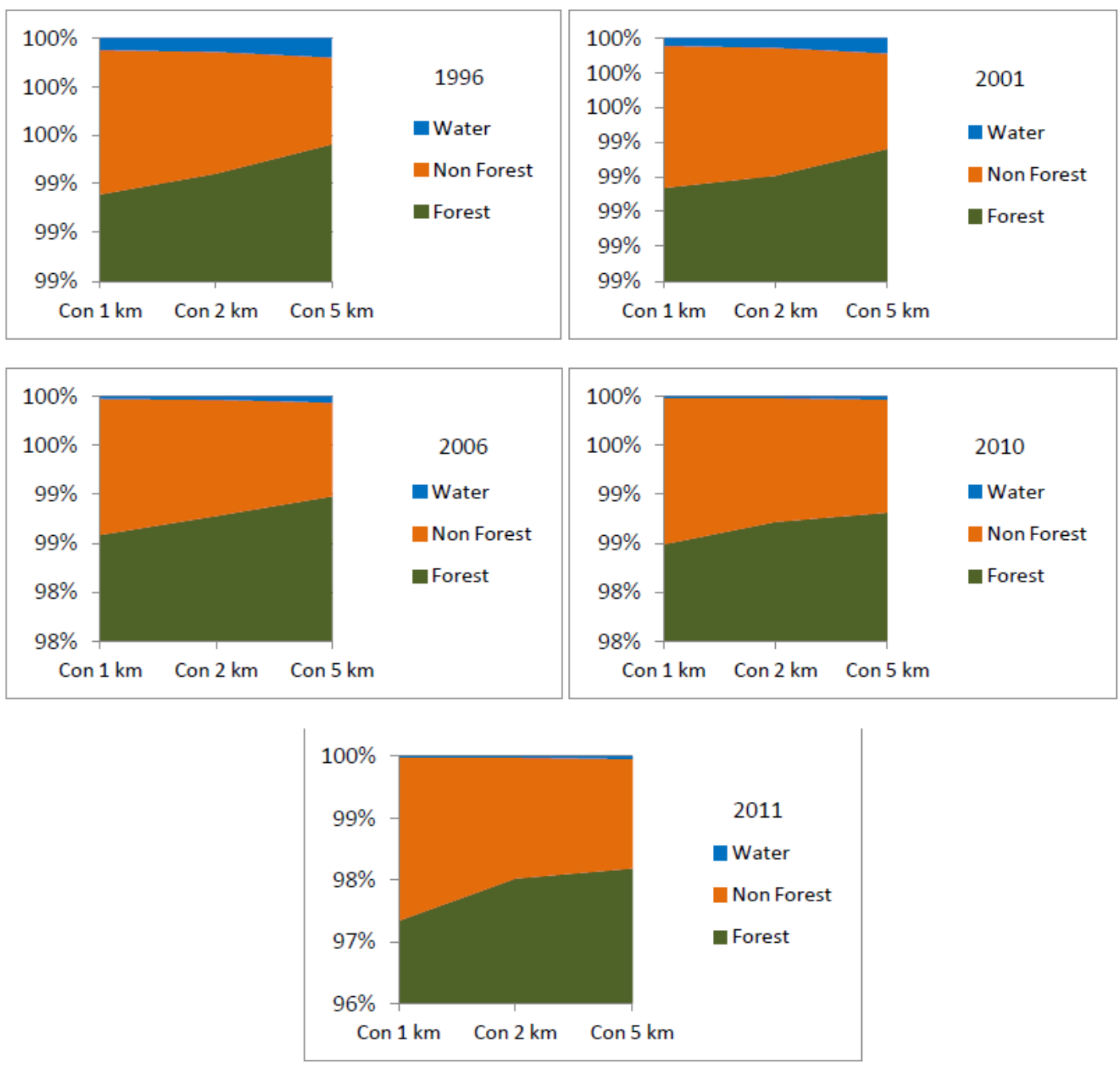

Land cover composition within the concession areas resembles that of the whole study area and the Tahuamanu province. In contrast to private agricultural titled lands, LULCC remained relatively stable across concession road network buffers throughout the years. Forest areas were dominant and non-forest areas were held constant within $1 \mathrm{~km}$ buffer until 2010, with a noticeably slight increase in 2011 . Few changes were visible between the $2 \mathrm{~km}$ and $5 \mathrm{~km}$ buffer zones (Figure 7). The results suggest that timber concession have been effective in stopping most forest clearance adjacent to timber concession 
roads since there has been very little change in percentage change over time. However, SFM actual practices could nonetheless diverge [83].

Overall, deforestation dynamics were more pronounced in agricultural lands along the IOH than in forest concessions and protected areas farther from the IOH. In this sense, land tenure categories and their use rules themselves reflect distance to the $\mathrm{IOH}$. While agricultural properties along the highway involve forest conversion, timber concessions and the Indigenous Community of Bélgica still preserve large tracts of intact forest. Overall, the changes seem to be moderate and driven by distance to major roads and secondary road accessibility. This occurs because roads have given access to areas for expanded agriculture use such as mechanized crops and in special pasture, whereas SFM have tried to keep agricultural expansion out of their areas. All that said, the tenure-distance correspondence is not universal. Forest conservation has not been successful around the town of Iberia, where agriculture has advanced into timber concession areas. Rule-breaking of this sort however has its own explanation in yet another factor operating: timber concession boundaries overlap with private agricultural lands [34]. Hence rule-breaking is itself tied to a lack of clarity concerning boundaries of lands with different use rules.

Changes along the Tahuamanu River show an almost stable forest ranging from $94 \%$ to $92 \%$ along the $1 \mathrm{~km}$ buffer throughout the analyzed timeline and a gradual increase in forested areas away from the river up to the $5 \mathrm{~km}$ buffer (Figure 8). Non-forest areas gradually increased from $2 \%$ to $5.5 \%$ within the $1 \mathrm{~km}$ buffer suggesting an increase in pasture and mechanized agriculture areas since 2006 around Iberia and specifically within the religious agrarian community Arca Pacahuara. The most discernible changes occurred close to the river while the 2 to $5 \mathrm{~km}$ buffers only changed slightly over the years.

The results suggest a very interesting trend for riverine settlements in the Amazon. The graphs show a similar distance decay effect in forest clearance along rivers than along roads however the development is less slowly than for roads. LULCC dynamics along rivers and closer to urban centers and road networks may unfold the same way than for roads. More research is needed to assess the trajectory of change for riverine settlements and if they vary according to land tenure and infrastructure polices [25-27,31,84]. So far, policies of infrastructure and tenure have spared LULCC changes within timber concessions and protected areas located away from road and river networks.

Figure 8. Forest, non-forest and water land-cover change dynamic of $1 \mathrm{~km}, 2 \mathrm{~km}$, and $5 \mathrm{~km}$ river buffer along the Tahuamanu River for 1996, 2001, 2006, 2011 for the Province of Tahuamanu.

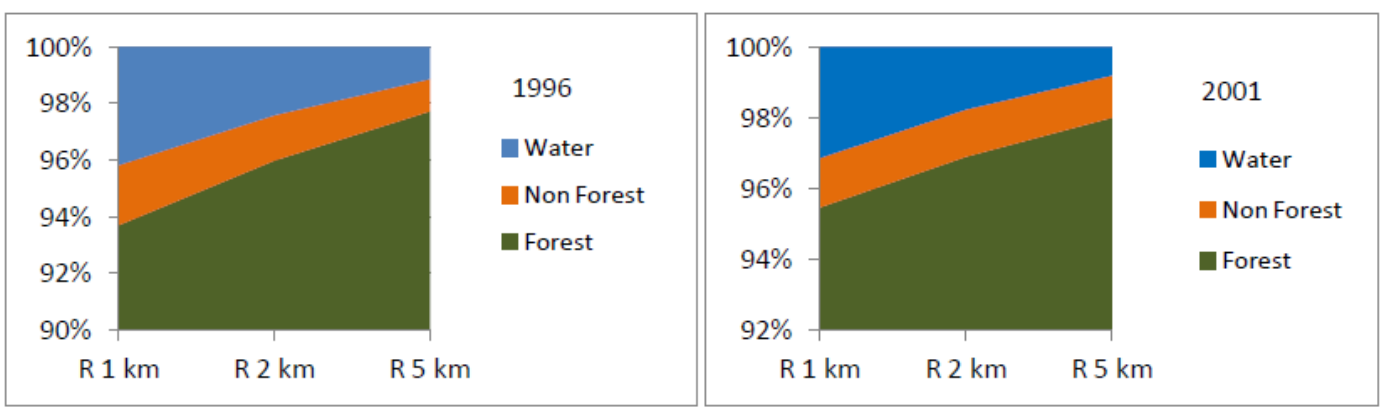


Figure 8. Cont.

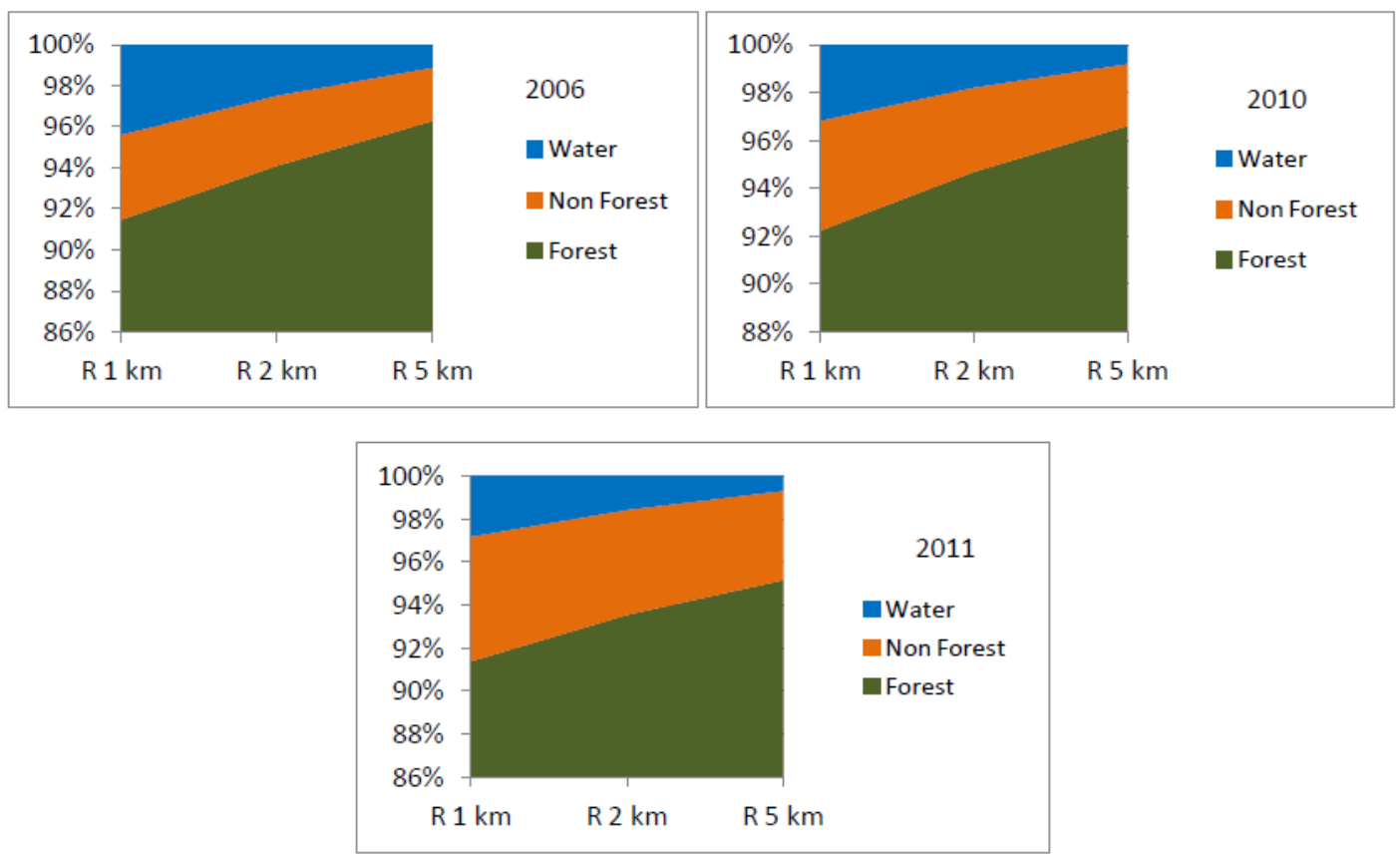

The pattern of LULCC resulting from road network expansion as described here has been reported in several studies from the Amazon [85-87]. In our case study, policy environments, land tenure categories, new infrastructure, and landholder characteristics are important determinants to what is happening and may continue to happen in the province of Tahuamanu. These determinants have been observed in other case studies sharing similar characteristics $[12,13,18,33]$. The paving of IOH and the expansion of a secondary road network facilitated the development of land areas for ranching, agriculture via mechanized crops, and fish farming [18,19,30,88-90]. Although farmers have often converted land for pasture, this does not necessarily mean that they will engage in a cattle economy. Research on successful cattle expansion in other parts of the Amazon has shown that the presence of market opportunities, state-supported technology transfer, and research on improved pasture management techniques are essential conditions for efficient livestock production [9,91]. These conditions have long been lacking in Peru. Large investments for sustaining a cattle economy have not taken place in Peru, although an improved local cattle economy is slowly growing in the District of Iñapari. A contributing factor is the strategic location of the Province of Tahuamanu next to Brazil, a leading beef producer and exporter country.

While in most frontier areas, LULCC has been accompanied by technology transfer via enhanced market access [92], this is still missing in Tahuamanu Province. New policies at the regional governmental level have started to promote some planning and monitoring of a more specialized technological and economic frontier corridor [52]. Despites this initiative, investment, new market centers, and secondary transformation production systems are still absent in Tahuamanu Province [46]. Nonetheless, landholders with superior productive capacity (i.e., more land, labor and/or capital) will be in a better position to benefit from policies and increased market opportunities by new infrastructure and thus modify their land use [11,93-95]. 


\subsection{Discussion on Variation in LULCC among Tenure Types and Overlaps}

We have provided results on spatial and temporal variation in forest loss, both by distance from the $\mathrm{IOH}$ and other roads as well as rivers, and by land tenure type. Although the findings shed light into how transportation infrastructure and land tenure have played a key role in the way LULCC has evolved across space and over time, the reality is by far more complex. Results in Figure 9 address the issue of overlap and unclear control access to resources within land tenure types and how it affects LULCC.

Figure 9. Overlap of agricultural areas and timber concession close to the town of Iberia and the Tahuamanu River.

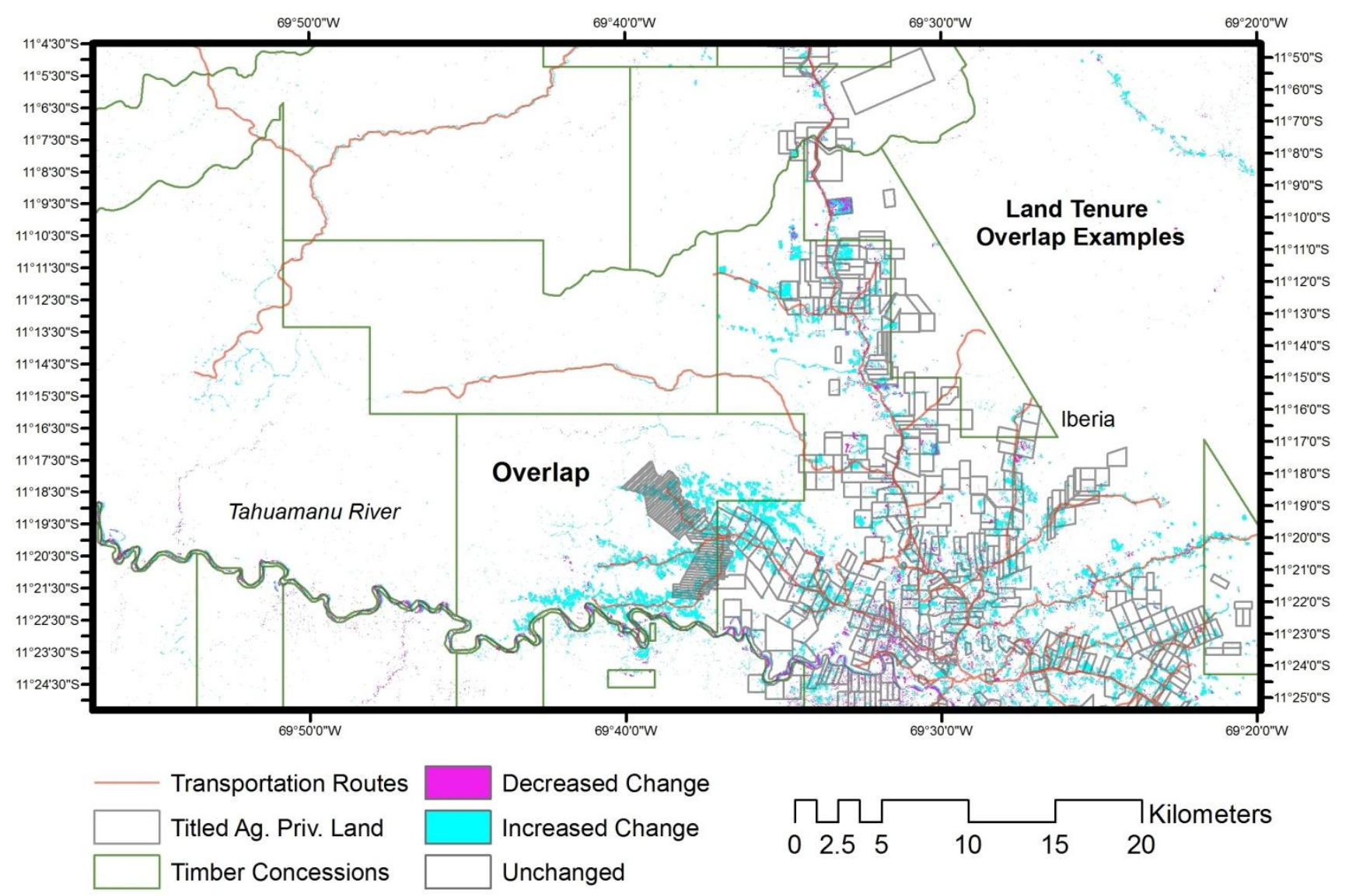

The detection of 2006-2011 change areas in Figure 9 confirms overlap between agricultural areas and timber concessions especially next to the town of Iberia and along the Tahuamanu River. The imprecise boundary conflicts between tenure types noticeably increases the uncontrolled expansion of cleared areas into timber concession areas. According to reports from the field, timber concessions have increasingly entered into agricultural lands benefitting from the lack of surveillance of the corresponding authorities. By doing so, timber concessions have been circumventing the legal requirements faced as concession holders to pay harvest and yearly area-based fees. On the other side, colonists have increasingly extracted timber from their agricultural lands in cooperation with timber concessions. It is well known in the Iberia District that timber extracted from titled agricultural lands is much higher than the official amount reported from timber concessions [49]. In these cases, logging occurs as a precursor to clearing for planting or ranching. Although we are not able to separate logging 
clear-cuts from agriculture clearing as a result of our classification, further research on this issue is needed to understand the implications for LULCC.

Concerns about the regulatory environment, together with a growing population of colonists, have increased exploitation of standing timber through clear cutting. According to [34], land tenure claimed rights for agriculture areas and acquired rights for timber concessions have long affected LULCC patterns. A step forward toward an improved framework of territorial rearrangement has been the preparation and analysis toward an Economic Ecological Zoning (EEZ). The EEZ of the Peruvian Amazon Region is a legal norm under the Peruvian Constitution Art. 69, which defines a dynamic and flexible process for the identification of diverse alternatives to the sustainable use of a territory based on the analysis of its potentials and limitations through the assessment of physical, biological, social, economic and cultural criteria. EEZ is intended as a form of land use planning tool that takes into consideration all aspects of the physical-biotic environment on the one hand and the socio-economic environment on the other. In Madre de Dios, the EEZ has been finalized in 2009 and should be used as an unbiased tool for the various land users to arrive at a consensus on the optimal use or non-use of the land and subsequent execution of legislative, administrative and institutional action on demarcated spatial units. For the Peruvian case, it is still unclear how the EEZ will influence already established land tenure systems into planning procedures that incorporate actual use and occupation of the territory and regularizes tenure overlaps. However, a first step is to acknowledge overlap areas at jurisdictions of different instances within the Regional Governments and work toward an integrated land tenure regularization process that reduce the effects on LULCC. As our case study reports, a defined land tenure category does not guarantee a clear control access of resources.

\section{Conclusions}

The study has contributed to the monitoring and evaluation of temporal patterns, spatial variation and spatio-temporal dynamics of deforestation in the Province of Tahuamanu. Deforestation is low overall in Tahuamanu, but exhibits non-linearities in its temporal trend. Forest loss occurred while preparations for paving the $\mathrm{IOH}$ were underway, and while deforestation does not seem to have occurred during paving, there was another decline in forest cover following paving. Spatially, deforestation is locally important adjacent to roads and rivers, which confirms previous work linking accessibility to LULCC. This study has confirmed that LULCC varies among land tenure types according to rules concerning land use and forest clearing; agricultural properties exhibit greater deforestation than other lands such as forest concessions and protected areas.

In terms of spatio-temporal dynamics, deforestation occurred primarily within buffers along roads, but especially around the time of highway paving. Hence, deforestation transpired mostly along roads and especially with paving of the $\mathrm{IOH}$. While the strongest spatio-temporal dynamics are evident closer to roads, the acceleration in deforestation with paving can still be detected out to $5 \mathrm{~km}$. Given the acceleration after 2010, it appears that expansion of non-forest areas will continue even further away than the $5 \mathrm{~km}$ distance buffer.

The paper suggests a very interesting trend for riverine settlements in the Amazon. A similar distance decay is in effect in forest clearance along rivers than along roads, however the development is less slowly than for roads. LULCC dynamics along rivers and closer to urban centers and road 
networks may unfold the same way than for roads. More research is needed to assess the trajectory of change for riverine settlements and if they vary according to land tenure and infrastructure polices.

Emphasis on clear land tenure demarcation should be a policy priority in Tahuamanu Province. The paving of the $\mathrm{IOH}$ has accelerated deforestation, including in forest concessions where boundaries overlap with agricultural lands. The interaction of highway paving and unclear tenure is thus a direct threat to efficient land use as well as forest conservation. Hence, lack of land demarcation and weak implementation of tenure policies are likely to hamper sustainable development.

The conclusion of paving of the $\mathrm{IOH}$ in Tahuamany raises additional questions about ensuing LULCC. While considerable previous work has shown that infrastructure construction and improvements yields short-run shifts in land use as via deforestation, there remains a need for attention to downstream dynamics such as intensification. There are incipient signs of this in Tahuamanu in the form of fish farming, which has very different implications for LULCC than, say, ranching. Prior work on land use intensification and LULCC has however produced mixed findings for frontier areas; in the case of the Amazon, the tendency has been for intensification along roads and near markets to coincide with expanding forest loss farther out, given conditions of land abundance in frontiers. More recent efforts to implement zoning plans have sought to combat this phenomenon by protecting ecologically sensitive areas and implement forest concessions with specific forest resources like timber and castaña. A key unresolved question in areas receiving infrastructure upgrades is thus whether the pressures to intensify while also expanding land use will ultimately outweigh land use regulations via establishment of protected areas and concessions. This topic deserves further attention as IIRSA unfolds in the context of zoning plans in many parts of the Amazon and elsewhere.

\section{Acknowledgments}

Funding for this research came from the United States Agency for International Development Initiative for the Conservation of Andean Amazon, RLA-A-00-06-00071-00 and the Compton Foundation. The authors would like to thank the contribution of Rogger Lopez, Edwin Jurado, Heber Baca, all MP-UNAMAD Consortia members, PEMD Iberia, Maderacre Timber Concession, Native Community Bélgica, and all inhabitants of Iñapari and Iberia. We are grateful to the Instituto Nacional de Recursos Forestales (INRENA) and Proyecto Especial de Titulación de Tierras (PETT) for providing GIS shape files used in this study. Three anonymous reviewers greatly improved the manuscript.

\section{References}

1. Land-Use and Land-Cover Change: Local Processes to Global Impacts; Lambin, E.F., Geist, H.J., Eds.; Springer-Verlag: Heidelberg, Germany, 2006.

2. Gutman, G.; Janetos, A.; Justice, C.; Moran, E.; Mustard, J.; Rindfuss, R.; Skole, D.; Turner, B.L., II. Land Change Science: Observing, Monitoring, and Understanding Trajectories of Change on the Earth's Surface; Kluwer Academic Publishers: Dordrecht, The Netherlands, 2004.

3. Geist, H.J.; Lambin, E.F. Proximate causes and underlying driving forces of tropical deforestation. BioScience 2002, 52, 143-150.

4. Fearhead, J.; Leach, M. Reframing Deforestation: Global Analyses and Local Realities: Studies in West Africa; Routledge: New York, NY, USA/London, UK, 1998. 
5. Malhi, Y.; Wright, J. Spatial patterns and recent trends in the climate of tropical rainforest regions. Phil. Trans. R. Soc. London 2004, 359, 311-329.

6. Angelsen, A.; Kaimowitz, D. Rethinking the causes of deforestation: Lessons from economic models. World Bank Res. Observ. 1999, 14, 73-98.

7. Hecht, S. Soybeans, development, and conservation on the Amazon Frontier. Dev. Change 2005, 36, 375-404.

8. Brondízio, E. S.; McCracken, S.D.; Moran, E.F.; Siqueira, A.D.; Nelson, D.R.; Rodriguez-Pedraza, C. The Colonist Footprint: Toward A Conceptual Framework of Land Use and Deforestation Trajectories among Small Farmers in the Amazonian Frontier. In Deforestation and Land Use in the Amazon; Wood, C.H., Porro, R., Eds.; University of Florida Press: Gainesville, GA, USA, 2002; pp. 133-161.

9. Aldrich, S. P.; Walker, R.T.; Arima, E.Y.; Caldas, M.M. Land-cover and land-use change in the Brazilian Amazon: smallholders, ranchers, and frontier stratification. Econ. Geogr. 2006, 52, 265-288.

10. Schmink, M.; Wood, C.H. Contested Frontiers in Amazonia; Columbia University Press: New York, NY, USA, 2002.

11. Walker, R.; Browder, J.; Arima, E.; Simmons, C.; Pereira, R.; Caldas, M.; Shirota, R.; Zen, S. Ranching and the new global range: Amazônia in the 21st Century. Geoforum 2009, 40, 732-745.

12. Carvalho, G.; Barros, A.C.; Moutinho, P.; Nepstad, D. Sensitive development could protect Amazonia instead of destroying it. Nature 2001, 409, 131.

13. Laurance, W.F.; Cochrane, M.A.; Bergen, S.; Fearnside, P.M.; Delmônica, P.; Barber, C.; D'Angelo, S.; Fernandes, T. The future of the Brazilian Amazon. Science 2001, 291, 438-439.

14. Andersen, L.E.; Reis, E.J. Deforestation, development and government policy in the Brazilian Amazon: an econometric analysis. Working Paper 513; Instituto de Pesquisa Econômica Aplicada (IPEA): Rio de Janeiro, Brazil, 1997.

15. Cattaneo, A. Deforestation in the Brazilian Amazon: Comparing the impacts of macroeconomic shocks, land tenure, and technological change. Land Econ. 2001, 77, 219-240.

16. Eden, M.J. Forest and Environmental Degradation. In Tropical Rain Forest: A Wider Perspective-Conservation Biology Series; Goldsmith, F.B., Ed.; Chapman \& Hall: London, UK, 1998; Volume 10, pp. 99-11.

17. Kaimowitz D.; Angelsen, A. Economic Models of Tropical Deforestation: A Review; The Council to Improve Foodborne Outbreak Response (CIFOR): Bogor, Indonesia, 1998.

18. Nepstad, D.; Carvalho, A.C.; Barros, A.; Alencar, A.; Capobianco, J.P.; Bishop, J.; Moutinho, P.; Lefebre, P.; Silva U.L.; Prins, E. Road paving, fire regime, feedbacks, and the future of Amazon forests. Forest Ecol. Manag. 2001, 154, 395-407.

19. Alves, D. An Analysis of the Geographical Patterns of Deforestation in the Brazilian Amazon in the Period 1991-1996. In Deforestation and Land Use in the Amazon; Wood, C.H., Porro, R., Eds.; University of Florida Press: Gainesville, GA, USA, 2002; pp. 95-106.

20. Gerencia Sub Regional de Madre de Dios (GESUREMAD). Plan Estratégico de Desarrollo del Departamento de Madre de Dios 1998-2008; GESUREMAD: Puerto Maldonado, Perú, 1998. 
21. Instituto Nacional de Desarrollo-Organización de los Estados Americanos (INADE-OEA). Plan de Desarrollo de las Comunidades Fronterizas Peruano-Brasileñas, Iñapari-Assis Brasi; Consejo Interamericano para el Desarrollo Integral de la Organización de los Estados Americanos (CIDI/OEA): Bogotá, Colombia, 1998.

22. Imbernon, J. A comparison of the driving forces behind deforestation in the Peruvian and the Brazilian Amazon. Ambio 1999, 28, 509-513.

23. Food and Agricultural Organization-United Nation (FAO). Actualización de la Evaluación de los Recursos Forestales Mundiales a 2005. Informe Final; Instituto Nacional de Recursos Naturales (INRENA): Lima, Perú, 2005.

24. World Bank. Análisis Preliminar Sobre Gobernabilidad y Cumplimiento de la Legislación del Sector Forestal en el Perú; World Bank: Washington, DC, USA, 2006.

25. Alvarez, N.; Naughton-Treves, L. Linking national agrarian policy to deforestation in the Peruvian Amazon: A case study of Tambopata, 1986-1997. Ambio 2003, 23, 269-274.

26. Mäki, S.; Kalliola, R.; Vuorinen, K. Road consequences in the Peruvian Amazon: Process, causes and consequences. Environ. Conserv. 2001, 28, 199-214.

27. Killeen, T.J. A Perfect Storm in the Amazon Wilderness: Development and Conservation in the Context of the Initiative for the Integration of the Regional Infrastructure of South America (IIRSA). Advances in Applied Biodiversity Science No 7; Conservation International: Arlington, VA, USA, 2007.

28. Dourojeanni, M. J.; Barandiaran, A.; Dourojeanni, D. Amazonia Peruana en 2021. Explotación de Recursos Naturales e Infraestructura. Que está Pasando? Que es lo que Significa para el Futuro? 1st ed.; GyG Impresores SAC: Lima, Perú, 2009.

29. Futemma, C.; Brondizio, E. Land reform and land-use changes in the lower Amazon: Implications for agricultural intensification. Hum. Ecol. 2003, 31, 369-402

30. Deforestation and Land Use in the Amazon; Wood, C.H., Porro, R., Eds.; University of Florida Press: Gainesville, FL, USA, 2002.

31. Walker, R.; Wood, C.H.; Skole, D.; Chomentowski, W. The Impact of Land Titling on Tropical Forest Resources. In Linking People, Place and Policy: A GIScience Approach; Walsh, S., Crews-Meyer, K., Eds.; Kluwer Academic Publishers: London, UK, 2002; pp. 131-153.

32. Nelson, A.; Chomitz, K.M. Protected Area Effectiveness in Reducing Tropical Deforestation: A Global Analysis of the Impact of Protection Status; World Bank Independent Evaluation Group, World Bank: Washington, DC, USA, 2009.

33. Fox, J. Understanding a Dynamic Landscape: Land Use, Land Cover and Resource Tenure in Northeastern Cambodia. In Linking People, Place and Policy: A GIScience Approach; Walsh, S., Crews-Meyer, K., Eds.; Kluwer Academic Publishers: London, UK, 2002; pp. 113-130.

34. Plan de Ordenamiento Territorial del Departamento de Madre de Dios al 2030; Documento de Trabajo para Consultas Publicas, Gobierno Regional de Madre de Dios (GOREMAD): Puerto Maldonado, Perú, 2011.

35. Naughton-Treves, L. Deforestation and carbon emissions at tropical frontiers: A case study from the Peruvian Amazon. World Dev. 2004, 32, 173-190. 
36. Consejo Nacional del Ambiente-Instituto Nacional de Recursos Naturales (CONAM-INRENA). Mapa de Deforestación de la Amazonia Peruana-2000; Memoria Descriptiva Volumen I-IM-03-02; PROCLIM/CONAM/INRENA: Lima, Perú, 2005.

37. Elgegren, J.; Lee, D. Deforestation in Peru. Working Paper; World Bank: Washington, DC, USA, 2006.

38. Alcalde, M. Diagnostico de la Deforestación en el Perú; Working Paper; USAIDINRENA-BIOFOR Activity: Lima, Perú, 2002.

39. National Institute of Statistics and Informatics (INEI). Análisis Socio Demográfico del Departamento de Madre de Dios; INEI: Lima, Perú, 2007. Available online: www.INEI.gob.pe (accessed on 26 May 2010).

40. Instituto Nacional de Estadística e Informática (INEI). Instituto Nacional de Estadística e Informática; INEI: Lima, Perú, 2004.

41. Chavez, A.; Perz, S. Adoption of policy incentives and land use: Lessons from frontier agriculture in Southeastern Peru. Hum. Ecol. 2012, 40, 525-539.

42. Tahuamanu Municipalidad Provincial. Plan Estratégico de Desarrollo; Documento de Trabajo; Tahuamanu, Peru, 2001.

43. Instituto de Investigaciones de la Amazonía Peruana (IIAP)/Consejo Transitorio de Administración Regional de Madre de Dios (CTAR-MDD). Madre de Dios, Camino al Desarrollo Sostenible: Propuesta de Zonificación Ecológica Económica Como Base Para el Ordenamiento Territorial; Impresiones C.E.T.A.: Iquitos, Perú, 2001.

44. Chavez, A. Public Policy and Spatial Variation in Land Use and Land Cover in the Peruvian Amazon. Ph.D. Dissertation, University of Florida, Gainesville, FL, USA, 2009

45. Consejo Transitorio de Administración Regional (CTAR). Plan Estratégico Concertado de Desarrollo Madre de Dios 2002-2004; CTAR: Puerto Maldonado, Perú; 2002.

46. Tarrier, D. Actualización del Plan Maestro del PNAP_Diagnostico Socio-Económico Cultural Sector Madre de Dios; Ministerio del Ambiente del Perú: Lima, Perú, 2010.

47. Ministerio de Agricultura/Instituto Nacional de Recursos Naturales (INRENA). Zonificación Ecológica-Económica Yaco-Iñapari e Iberia-Iñapari, Madre de Dios; Reporte Técnico; Lima, Perú, 1998.

48. Gobierno Regional de Madre de Dios (GOREMAD). Macrozonificación Ecológica Económica de Madre de Dios; GOREMAD: Puerto Maldonado, Perú, 2009.

49. Municipalidad Distrital de Iberia. Plan de Desarrollo Concertado del Distrito de Iberia al 2021; Unpublished Report, 2010.

50. Domínguez Del Aguila, S. Caracterización de la Cuenca del Rio Tahuamanu; Unpublished Report; Gobierno Regional Madre de Dios-Proyecto Especial Madre de Dios, Consorcio MP: Iberia, Perú, 2010.

51. Domínguez Del Aguila, S. Plan de Gestión Participativa de la Subcuenca del Rio Yaverija; Unpublished Report; Gobierno Regional Madre de Dios-Proyecto Especial Madre de Dios, Consorcio MP: Iberia, Perú, 2010.

52. Gobierno Regional de Madre de Dios-Proyecto Especial Madre de Dios (GOREMAD-PEMD). Estrategia para el Desarrollo y la Integración Fronteriza de Madre de Dios 2011-2021; GOREMAD/PEMD: Puerto Maldonado, Iberia, Perú, 2010. 
53. Nalvarte Armas, W.; Sabogal, C.; Thiel, H. Evaluación del Impacto del Cobro por Derechos de Aprovechamiento de Madera en pie y Otras Tasas Sobre el Manejo Forestal en Perú; Programa de Cooperación FAO/Banco Mundial; Food and Agricultural Organization of the United Nations (FAO-UN) and World Bank: Rome, Italy, 2012; Volume VI.

54. Domínguez Del Aguila, S. Comunidad Nativa de Bélgica: Propuesta de Plan de Ordenamiento Territorial Comunal; Unpublished Report; Gobierno Regional Madre de Dios, Proyecto Especial Madre de Dios, Consorcio MP, Iberia, Perú, 2010.

55. Broto, L.; Murray, J.; Pettenella, D.; Secco, L.; Masiero, M. Biodiversity in the Peruvian Amazon. ETFRN News 2010, 51, 112-119.

56. Che, P.H.; García, T. Estudio REDD Perú: La Situación de REDD en el Perú; Derecho Ambiente y Recursos Naturales (DAR): Lima, Perú, 2011.

57. Solano, P. Legal Framework for Protected Areas: Peru. In Guidelines for Protected Area Legislation; IUCN Environmental Policy and Law Paper, IUCN-EPLP No. 81; World Conservation Union: Gland, Switzerland, 2009.

58. Huertas Castillo, B. Indigenous Peoples in Isolation in the Peruvian Amazon; IWGIA Document No 100; International Work Group for Indigenous Affairs (IWGIA): Copenhagen, Denmark, 2004.

59. Herndon, W.L. Exploration of the Valley of the Amazon; McGraw-Hill: New York, NY, USA, 1952.

60. Instituto Nacional de Desarrollo-Proyecto Especial de Madre de Dios (INADE-PEMD). Plan Operativo Institucional para el año 2004; PEMD: Puerto Maldonado, Perú, 2004.

61. Instituto Nacional de Recursos Naturales-Organización de los Estados Americanos (INRENA-OEA). Zonificación Ecológica-Económica Yaco-Iñapari e Iberia-Iñapari; INRENA-OEA: Lima, Perú, 1994.

62. Green, G.M.; Schweik, C.M.; Randolph, J.C. Retrieving Land-Cover Change Information from Landsat Satellite Images by Minimizing Other Sources of Reflectance Variability. In Seeing the Forest and the Trees: Human-Environment Interactions in Forest Ecosystems; Moran, E.F., Ostrom, E., Eds.; The MIT Press: Cambridge, MA, USA, 2005; pp. 131-160.

63. Cohen, W.B.; Fiorella, M.; Gray, J.; Helmer, E.; Anderson, K. An efficient and accurate method for mapping forest clear cuts in the Pacific Northwest using Landsat imagery. Photogramm. Eng. Remote Sensing 1998, 64, 293-300.

64. Cohen, W.B.; Spies, T.A.; Alig, R.J.; Oetter, D.R.; Maiersperger, T.K.; Fiorella, M. Characterizing 23 years (1972-95) of stand replacement disturbance in Western Oregon forests with Landsat imagery. Ecosystems 2002, 5, 122-137.

65. Franklin, S.E.; Lavigne, M.B.; Moskal, L.M.; Wulder, M.A.; McCaffrey, T.M. Interpretation of forest harvest conditions in New Brunswick using Landsat TM enhanced wetness difference imagery (EWDI). Can. J. Remote Sens. 2001, 27, 118-128.

66. Seto, K.; Woodcock, C.E.; Song, C.; Huang, X.; Lu, J.; Kaufmann, R. Monitoring land use change in the Pearl River Delta using Landsat TM. Int. J. Remote Sens. 2002, 23, 1985-2004.

67. Collins, J.B.; Woodcock, C.E. Change detection using the Gramm-Schmidt transformation applied to mapping forest mortality. Remote Sens. Environ. 1994, 50, 267-279.

68. Fung, T. An assessment of TM imagery for land-cover change detection. IEEE Trans. Geosci. Remote Sens. 1990, 28, 681-684. 
69. Guild, L.S.; Cohen, W.B.; Kauffman, J.B. Detection of deforestation and land conversion in Rondônia, Brazil using change detection techniques. Int. J. Remote Sens. 2004, 25, 731-750.

70. Crist, E.P.; Cicone, R.C. A physically-based transformation of thematic mapper data-the TM tasseled cap. IEEE Trans. Geosci. Remote Sens. 1984, 22, 256-263.

71. Ivits, E.; Lamb, A.; Langar, F.; Hemphill, S.; Koch, B. Orthogonal transformation of segmented SPOT5 images: seasonal and geographical dependence of the tasseled cap parameters. Photogramm. Eng. Remote Sensing 2008, 74, 1351-1364.

72. Crist, E.P.; Lauren, R.; Cicone, R.C. Vegetation and Soils Information Contained in Transformed Thematic Mapper Data. In Proceedings of IGARSS'86 Symposium, Zurich, Switzerland, 8-11 September 1986; ESA Publ. Division: Noordwijk, The Netherlands; pp. 1465-1470.

73. Cohen, W.B.; Spies, T.A.; Fiorella, M. Estimating the age and structure of forests in a multi-ownership landscape of western Oregon, USA. Int. J. Remote Sens. 1995, 16, 721-746.

74. Fiorella, M.; Ripple, W.J. Determining successional stage of temperate coniferous forests with Landsat satellite data. Photogramm. Eng. Remote Sensing 1993, 59, 239-246.

75. Cohen, W.B.; Spies, T.A. Estimating structural attributes of Douglas-fir/Western Hemlock forest stands from Landsat and SPOT imagery. Remote Sens. Environ. 1992, 41, 1-17.

76. Aguilar, A. Remote sensing of forest regeneration in highland tropical forests. GISci. Remote Sens. 2007, 42, 66-79.

77. Kauth, R.J.; Thomas, G.S. The Tasseled Cap-A Graphic Description of Spectral-Temporal Development of Agricultural Crops as Seen by Landsat. In Proceedings of 2nd International Symposium on Machine Processing of Remotely Sensed Data, West Lafayette, IN, USA, 29 June-1 July 1976; LARS Purdue University: West Lafayette, IN, USA; pp. 41-51.

78. Huang, C.; Wylie, B.; Homer, C.; Yang, L.; Zylstra, G. Derivation of a tasseled cap transformation based on Landsat 7 at-satellite reflectance. Int. J. Remote Sens. 2002, 23, 1741-1748.

79. Pachauri, R.K., Reisinger, A. Climate Change 2007: Synthesis Report-Contribution of Working Groups I, II and III to the Fourth Assessment Report of the Intergovernmental Panel of Climate Change; Intergovernmental Panel on Cimate Change (IPCC): Geneva, Switzerland, 2007.

80. Food and Agricultural Organization of the United Nations (FAO-UN). Global Forest Resources Assessment 2005. Progress towards Sustainable Forest Management; FAO-UN: Rome, Italy, 2006.

81. Congalton, R.G.; Green, K. Assessing the Accuracy of Remotely Sensed Data Principles and Practices, 2nd ed.; CRS Press, Taylor and Francis Group: London, UK, 2008.

82. Lu, D.; Mausel, P.; Batistella, M.; Moran, E. Land-cover binary change detection methods for use in the moist tropical region of the Amazon: A comparative study. Int. J. Remote Sens. 2005, 1, 101-114.

83. Urrunaga, J.M.; Johnson, A.; Orbegozo, I.D.; Mulligan, F. The Laundering Machine-How Fraud and Corruption in Peru's Concession System are Destroying the Future of its Forests; Environmental Investigation Agency: Washington, DC, USA, 2012.

84. Arce-Nazario, J.A. Human landscapes have complex trajectories: reconstructing Peruvian Amazon landscape history from 1948 to 2005. Landsc. Ecol. 2007, 22, 89-101.

85. Arima, E.; Walker, R.T.; Perz, S.; Caldas, M. Loggers and Forest Fragmentation: Behavioral models of road building in the Amazon basin. Ann. Assoc. Am. Geogr. 2005, 95, 525-541. 
86. Pfaff, A.; Robalino, J.; Walker, R.; Aldrich, S.; Caldas, M; Reis, E.; Perz, S.; Bohrer, C.; Arima, E. Road investment, spatial spillovers, and deforestation in the Brazilian Amazon. J. Reg. Sci. 2007, 47, 109-123.

87. Redo, D.J. Mapping land-use and land-cover along Bolivia's Corredor Bioceánico with CBERS and the Landsat series: 1975-2008. Int. J. Remote Sens. 2012, 33, 1881-1904.

88. Wood, C.; Skole, D. Linking Data to Study Deforestation in the Brazilian Amazon. In People and Pixels-Linking Remote Sensing and Social Science; Liverman, D., Moran, E., Rindfuss, R., Stern, P., Eds.; National Academy Press: Washington, DC, USA, 1998; pp. 70-93.

89. Mertens, B.; Poccard-Chapuis, R.; Piketty, M.G.; Lacques, A.E.; Venturieri, A. Crossing spatial analyses and livestock economics to understand deforestation processes in the Brazilian Amazon: The case of Sao Felix do Xingu in South Para. Agric. Econ. 2002, 27, 269-294.

90. Kaimowitz, D.; Mendez, P.; Puntodewo, A.; Vanclay, J. Spatial Regression Analysis of Deforestation in Santa Cruz, Bolivia. In Deforestation and Land Use in the Amazon; Wood, C.H., Porro, R., Eds.; University of Florida Press: Gainesville, GA, USA, 2002; pp. 41-65.

91. Piketty, M.G.; Veiga, J.B.; Tourrand, J.F.; Alves, A.M.; Poccard-Chapuis, R.; Thales, M.C. The determinants of the expansion of cattle ranching in the Eastern Amazon region: consequences for public policies. Cahier Agric. 2005, 14, 90-95.

92. Andersen, L.E.; Granger, C.W.; Reis, E.J.; Weinhold, D.; Wonder, S. The Dynamics of Deforestation and Economic Growth in the Brazilian Amazon; Cambridge University Press: New York, NY, USA, 2002.

93. Arima, E.; Walker, R.; Salas, M.; Souza, C., Jr; Perz, S. Emergent Road Networks and the Fragmentation of Space in the Amazon Basin. Photogramm. Eng. Remote Sensing 2008, 74, 699-709.

94. Perz, S.G.; Walker, R.T.; Caldas, M.M. Beyond population and environment: Household life cycle demography and land use allocation among small farm colonists in the Amazon. Hum. Ecol. 2006, 34, 829-849.

95. Caldas, M.; Walker, R.; Perz, S.; Arima, E.; Aldrich, S.; Simmons, C. Theorizing land cover and land use change: The peasant economy of colonization in the Amazon Basin. Ann. Assoc. Am. Geogr. 2007, 97, 86-110.

(C) 2013 by the authors; licensee MDPI, Basel, Switzerland. This article is an open access article distributed under the terms and conditions of the Creative Commons Attribution license (http://creativecommons.org/licenses/by/3.0/). 